\title{
Pontic Athens An Athenian Emporion in Its Geo-Historical Context
}

\author{
Altay COŞKUN*
}

\section{1) Pontic Athens in the High and Later Roman Empire: Literary Evidence and Topography}

Stephanos of Byzantion lists altogether nine places called Athens in his Ethnika (A 80). The least significant among them was located on the coast of the Pontos Euxeinos. The information the $6^{\text {th }}$-century lexicographer provides is meagre and nearly confined to mentioning that it had 'a Greek sanctuary' (hieron Hellenikon). Stephanos does not call the place a polis, but only chorion ('place', 'settlement' or 'fort'). His most recent editor, Margarethe Billerbeck, translates this as 'Festung', without giving any further comment. She is thus in good company with most of our ancient sources (see below) and modern authorities, who do not deem worthy Pontic Athens of a mention, let alone discussion. ${ }^{1}$ However, this Athenai deserves some more scholarly attention, not only because it carries the name of the most famous of all ancient Greek cities ${ }^{2}$ and hosted a castle in the Roman, Byzantine, Trapezuntine and Ottoman periods, ${ }^{3}$ but also because it continues to be inhabited to the present day. The town Pazar on the north-eastern Black-Sea coast of Turkey, in the province of Rize, appears to be its modern successor, which even maintained its ancient name Atina until recently. Pazar is located at a distance of $111 \mathrm{~km}$ from Ortahisar (near Trabzon/Trapezunt) or about $40 \mathrm{~km}$ from Rize/Rhizaion. ${ }^{4}$

Since Stephanos explicitly references Arrian as his source, we can avoid speculating about Athenai's conditions in the early-Byzantine period and immediately turn to the more complete original account. The historiographer and philosopher from Nikomedeia served the Emperor Hadrian as the governor of Kappadokia in the 130s AD. The Periplous Pontou Euxeinou is his report which resulted from the inspection of the coastline under his supervision, perhaps in $A D$ 132. ${ }^{5}$ Arrian (PPE 3.4-7.3), too, calls Athenai a chorion and mentions it as the last anchorage af-

* Assoc. Prof. Altay Coşkun, University of Waterloo, Ontario, Canada (altay.coskun@uwaterloo.ca; https://orcid.org/0000-0002-4672-6195).

${ }^{1}$ Billerbeck 2006, 69. It is marginalized through the correction of Müller (see below) and missing in the account and notes of Magie 1950 (though figures on his map). It is entirely omitted, e.g., by Kahrstedt 1934, 32-41; Olshausen - Biller 1984; Marek 2003; 2010; Avram - Hind - Tsetskhladze 2004; Braund 2005; Mattingly 2008; Azoulay 2014; BNP. An exception is Kakhidze 2005, 117, who lists Atina among the tax-paying members of the Athenian League (without comment).

${ }^{2}$ For a similar argument, see Arr. PPE 5.3 (addressing Hadrian), cf. Silberman 1995, 4 n. 26.

${ }^{3}$ See Bryer - Winfield 1985, 335-339.

${ }^{4}$ Tomaschek 1896, 2022; Bryer - Winfield 1985, 335-339 (also knowing the name variants Sindena

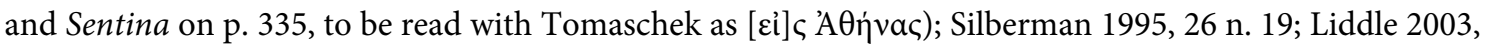
94. Distances in km have been calculated with Google Maps (11 Jan. 2019).

${ }^{5}$ See Rémy 1989, 213-217 (AD 131/32-136/37); Braund 1994, 178 (AD 132); Silberman 1995, VII (AD 131 or 132); Tsetskhladze 1998, 15; cf. 49f. (AD 134); Liddle 2003, 5-12 (AD 131/138); Belfiore 2009, 36 
ter Hyssou Limen before Apsaros, a major Roman fortress housing five cohorts (at least 2,000 soldiers) on the southern bank of the Akampsis River near the border to Kolchis. More precisely, he locates it east of Trapezous/Trabzon (720 stades $=$ ca. $108 \mathrm{~km}$ ), of the Rhizaion River/Rize Çayı $(270$ stades $=$ ca. $40.5 \mathrm{~km})$ and of the Adienos River $(180$ stades $=$ ca. $27 \mathrm{~km})($ see map $){ }^{6}$ The same Athenai is situated 7 stades west of the Zagatis River, the Hemşin Deresi, ${ }^{7}$ which merges into the Black Sea in Pazar. The site of this modern settlement is therefore to be distinguished from its ancient predecessor, at least from its harbour, which probably lay a bit more than 1 $\mathrm{km}$ further west. This way, the anchorage benefitted from the little nose which is now marked by the Trapezuntine-Ottoman 'Girl's Castle' (Kiz Kalesi). ${ }^{8}$ According to Arrian, the harbour was to some degree sheltered against the south and east winds, ${ }^{9}$ whence he was stuck there for two days with part of his fleet.

The relevant sections of his report read as follows:

For there is upon the Euxine sea a place so called (sc. Athenai), where there is a temple in the Greek style, from which circumstance the place seems to me to have derived its name. There is a ruined castle at this place.

The port is such that, in this season of the year, it cannot indeed contain many ships ${ }^{10}$ but is sufficient to afford them a shelter from the south wind, and even from the south-east. Ships that put in there might indeed be safe from the north-east wind, but not from the north, nor from that wind which is called Thraskias in Pontus, but Skiron in Greece.

(131/32); Rood 2011 (130s). My impression is that the Periplous reports Arrian's first inspection of the Pontic coast, thus around 132 BC.

${ }^{6}$ Arr. PPE 7.1-3. A stade is normally measured at 600 feet or $177.42 \mathrm{~m}$ respectively, which would yield ca. $128 \mathrm{~km}$. But Bauslaugh 1979, esp. 5 n. 22 demonstrates that, in practice, there was a significant variance, normally between 150 and 200 m per stade. Depending on where exactly the ancient harbours were located, how closely the coastline was followed (or what distance had to be kept due to cliffs), and how freely numbers were rounded (Arrian mostly uses multiples of 30 stades), the effective distance between Trapezous and Athenai was ca. 100 to $110 \mathrm{~km}$. I suggest that $150 \mathrm{~m}$ comes close to Arrian's average stade. Also compare the 180 stades $/ 27 \mathrm{~km}$ between the mouth of the Adienos and the harbour of Athenai with the distance of $16 \mathrm{mi}$ les $/ 24 \mathrm{~km}$ of the land route from Ardinium, as below. On Apsaros, see below, with n. 57.

${ }^{7}$ Named after Google Maps (11 Jan. 2019), whereas Bryer - Winfield 1985, 337 call it Pazar or Susa Dere; cf. Belfiore 2009, 160 for Pazar Dere.

${ }^{8}$ Bryer - Winfield 1985, 339 no. 1: 'K1z Kulesi'. Cf. Belfiore 2009, 161.

${ }^{9}$ Tomaschek 1896, 2022 may be exaggerating, but, from Arrian's perspective (and probably also Ptolemy's, see below), he is right to view the shelter as the main advantage of the place.

${ }^{10}$ My translation. Cf. Falconer 1805: 'a port, which in the summer season cannot indeed contain many ships'. This would imply a higher overall capacity than the translation by Silberman 1995, 3 or Liddle 2003, 55: 'The mooring at the right time of the year can accommodate a few ships'. The Greek is somewhat unclear, and I wonder if a demonstrative pronoun has fallen out before ẅpạ. Cf. Belfiore 2009, 140: 'accogliere nella buona stagione non molte navi'. 
During the night, there came on a violent storm of thunder and lightning; nor did the wind continue in the same direction, but came about to the south, and soon after from the south to the south-west, and the anchorage was no longer safe for our ships. ${ }^{11}$

Therefore, before the sea had begun to rage violently, we drew up into the harbour of Athenai as many of our ships as it would contain, excepting the one trireme, which, having found a convenient shelter under cover of a rock, rode there in safety.

It seemed proper also to send the larger part ${ }^{12}$ of our vessels to the neighbouring shores to be drawn aground. This succeeded so well that they all escaped safe, except for one, which, upon entering the bay, exposed its side improperly to the wind, and the swell of the sea drove it ashore and wrecked it.

Everything on board, however, was saved, not only the sails, nautical instruments and men, but also the bolts. ${ }^{13}$ We even scraped off the wax, so that nothing else was needed for the construction than shipbuilding timber, of which there is, as You (sc. Hadrian) know, a great quantity in the district of Pontos.

The storm continued two days, and necessarily detained us during that time. It would indeed have indicated a want of respect to have passed by Athenai, ${ }^{14}$ even the one of that name in Pontos, as if it were some deserted and nameless port. ${ }^{15}$

${ }^{11}$ My translation. Falconer 1805 may have read a slightly different Greek text: 'which rendered the bay, or road, in which we lay, no longer a safe station'. The description of the winds follows a literary tradition, but may still be realistic; see Belfiore 2009, 159-161.

${ }^{12}$ Cf. Belfiore 2009, 140. Misunderstood by Liddle 2003, 55 as 'the large ships'.

${ }^{13}$ My translation, following Silberman 1995, 3f. and cf. Belfiore 2009, 141. Falconer seems to have read a partly different Greek text, but also changed the word order to imply Arrian's greater concern for the men than for the bolts.

${ }^{14}$ Thus, the free but fitting translation by Falconer 1805. More litteral would be: 'It was thus not permitted to us to sail by Athens in Pontos as if it were an abandoned and anonymous anchorage.'

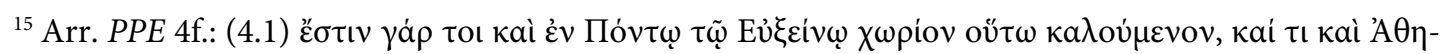

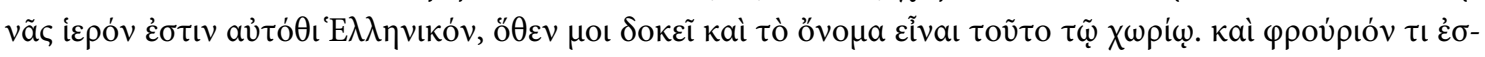

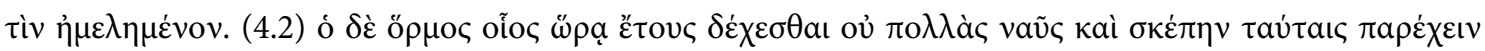

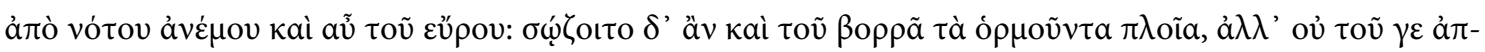

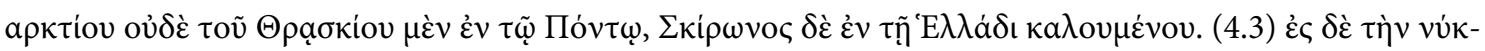

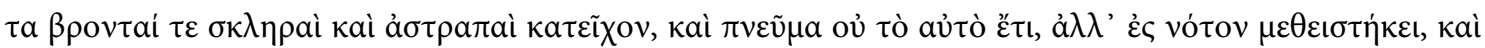

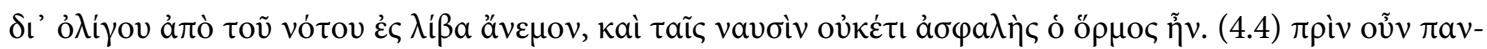

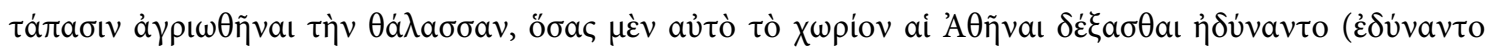

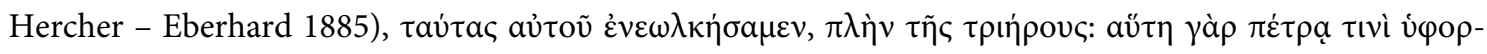

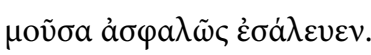

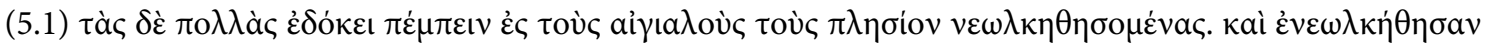

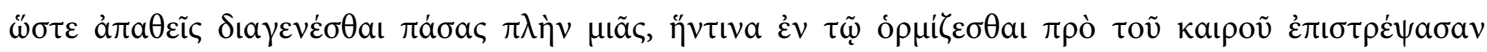

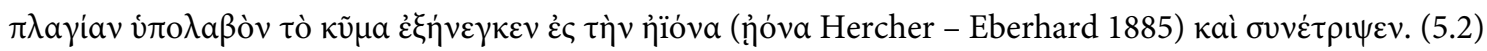

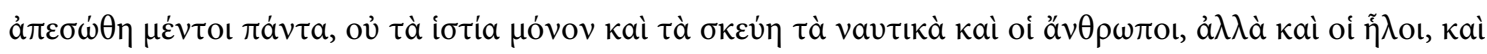

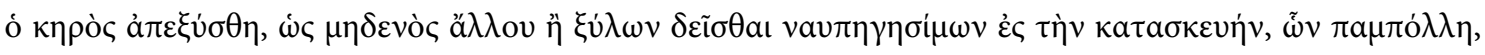

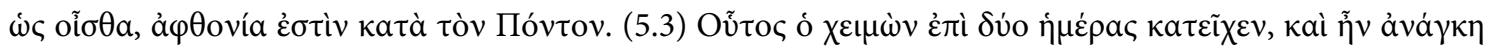

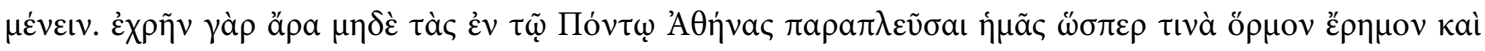
ảvóvvuov. 
That the nose was the defining feature of the place may also be implied by the Geography of Arrian's contemporary, Claudius Ptolemy (5.6.6), who locates a certain Athenōn Akron after Rhizous Limen and Chordybe. This said, his coordinates demonstrate that he conceived Pontic Athens as a clear-cut promontory, standing out more pronouncedly from the coastline than the actual nose does. ${ }^{16}$ It would thus seem to me that this little Athens on the Euxine coast was significant enough to extend its name to the whole cape between the city of Çayeli to its west and Beyaztaş, an eastern quarter of Pazar, to the east. The diameter of this promontory, beside whose nose Athenai sits, is about $20 \mathrm{~km} \cdot{ }^{17}$ However, to understand Ptolemy's perspective, we need to turn to older editions of his Geography, which have not yet changed the transmitted 'A $\theta \eta v \tilde{\omega} v$ ök-

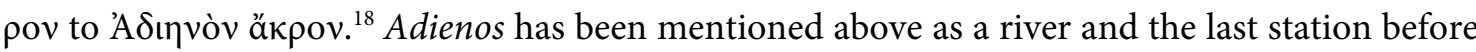
Athenai, probably now the Büyük Çayı, which merges into the Black Sea at the west end of the aforesaid Çayeli. The latter, in turn, seems to be the predecessor to the station Ardinium, which the Tabula Peutingeriana locates 16 miles (ca. $24 \mathrm{~km}$ ) before Athenai. ${ }^{19}$ The ancient tradition

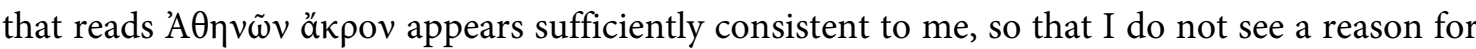
'correcting' it to Asııvòv äkpov.

It is not entirely clear whether Arrian's Periplous implies that there existed a settlement however small at Athenai. Its representation or its neglect in modern scholarship conveys the impression that the place was entirely abandoned. In accordance with this view, Arrian does not refer to any interpersonal encounters with locals during his involuntary visit. ${ }^{20}$ But I would rather assume that there was a village at his time, because he only calls the 'fort neglected' (rather than abandoned) and speaks of the 'anchorage' (hormos) 'as if it were abandoned and without name'. That this is a contrary-to-fact comparison should be obvious, because Arrian does give us a name for

The Greek text has been adapted from the ed. by Hercher - Eberhard 1885; cf. the eds. by Roos - Wirth 1967, Silberman 1995, Liddle 2003, and Belfiore 2009. The translation has been adapted from Falconer 1805 ( $\$$ 3f.), after comparison with Silberman 1995 (French), Liddle 2003 (English), and Belfiore (Italian).

${ }^{16}$ The transmitted coordinates are $o \alpha^{\circ}-\mu \gamma^{\circ} L \delta^{\prime}=71^{\circ}-43^{\circ} 45^{\prime}$. Stückelberger - Graßhoff 2006, vol. 2, 514f. correct in $\mathrm{oq}^{\circ}\left(\delta^{\prime}\right)-\mu \gamma^{\circ} \mathrm{L} \delta^{\prime}=71^{\circ}\left(15^{\prime}\right)$ - $43^{\circ} 45^{\prime}$, but their map on p. 847 ('Karte Asien 1') represents the original location, whereas the 'correction' would yield a relatively even coastline. Also see next $\mathrm{n}$.

${ }^{17}$ I recommend the satellite images of Google Maps, to gain an impression of the coastline and the location of Pazar.

${ }^{18}$ The reading of the codd. is maintained by Nobbe 1843-45/1966, 27; cf. Miller 1916, 648. Stückelberger - Graßhoff 2006, vol. 2, 514 reference the ed. by Müller 1883/1901, which is inaccessible to me. But Wikipedia.com s.v. Athenae (Pontus) may give us a clue, since it refers to the geographer Konrad Mannert (ca. 1800) for the assumption that Ps.-Skylax, Asia 83 meant to denote Pontic Athens as Odeinios, but this is called a polis and probably relates to Adienios/Ardinium, on which see below.

${ }^{19}$ Cf. Miller 1916, 648 and Silberman 1995, 28 for some minor variation and further ancient sources; 'Kanlüdere' or rather Kanlidere seems to be an older name for the town, which is still maintained in the name of a minibus station, see Google Maps for Çayeli Kanlıdere Minibüs Durağı. I could not verify the name 'Kemer Burun', which Stückelberger - Graßhoff 2006, vol. 2, 515 propose. It may relate to the much larger promontory east of Çayeli, on whose tip Athenai/Pazar is located.

${ }^{20}$ Cf. Counillon 2004/14, 61; Belfiore 2009, 160; Dewing - Kaldellis 2014, 465 n. 741: 'Arrian ... who says that it was abandoned.' 
the place, and further derives it from the sanctuary of Athena located there. He does not, however, explain who had established the sanctuary in the first place.

After Arrian and Ptolemy, our record is silent again for about two centuries. While not yet mentioned in the $3^{\text {rd }}$-century Itinerarium Antonini, ${ }^{21}$ Athenai figures again in the Tabula Peutingeriana (10.3f.), where it is located in the middle of the route from Trapezous to Apsaros, in-between Reila/Rhizaion and Ardinium to its left and Abgabes to its right. It also shows up in the Late-Roman anonymous Periplous, which reproduces much of Arrian's text, and the Byzantine Cosmographia Ravennatis. ${ }^{22}$ Accordingly, Pontic Athens must have received a relay station of the cursus publicus by the $4^{\text {th }}$ century. ${ }^{23}$

\section{2) Tracing the Origin of Pontic Athens}

There is one further mention of Athenai at the end of antiquity. In the $6^{\text {th }}$ century, Prokopios writes:

Beyond Rhizaion are found the boundaries of independent peoples, who live between the Romans and the Lazoi. There is a certain village named Athenai, not, as some suppose, because Athenian colonists settled there, but because a certain woman named Athenaia ruled over the land in early times. Her tomb is still there even to my day. ${ }^{24}$

Although Prokopios dedicates no more than this short paragraph to the 'village', as he now classifies the settlement, he feels the need to contradict rumours that it derived from Attika. But his recourse to an eponymous Lady Athenaia carries little weight. He seems to have fallen prey to a local legend, apparently a Christian reinterpretation of the Athena cult. ${ }^{25}$ At any rate, claiming one's origin from erstwhile glorious Athens a millennium after its naval thalassocracy had collapsed is not in itself a strong argument either. At least, some compelling traces in the material remains or literary evidence would be desireable to support such a connection. Due to their absence, scholars agree with Prokopios on rejecting the villagers' lofty pretensions. But we need to be cautious not to jump too quickly to a conclusion that is methodologically unsound: we cannot, on the one hand, deny an Athenian settlement because of the lack of archaeological data from the Classical period, while admitting on the other hand that there is no evidence for a Ro-

\footnotetext{
${ }^{21}$ There does not yet seem to have existed an imperial road along the coast connecting Trapezous with other cities, let alone Athenai. The former was connected by land only to Satala via the Zigana Pass: Itin. Ant. 216.4-217.4; cf. Erciyas 2007, 1199.

${ }^{22}$ Anon. PPE 8r40-43 ed. Diller 1952, 126. Cf. Tomaschek 1896, 2022; Miller 1916; 648f.

${ }^{23}$ On the Late-Roman cursus publicus, a much-enhanced version of the high-imperial communication system, see Lemcke 2016.

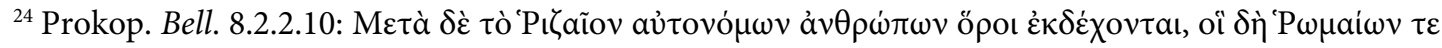

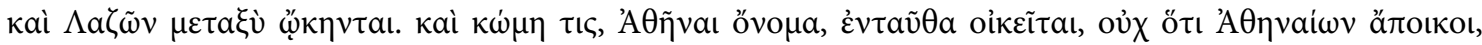

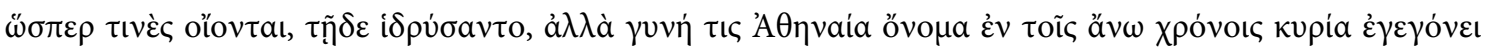

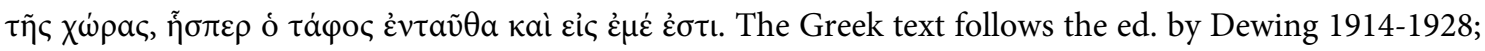
cf. Veh 1978. The translation has been adapted from Dewing - Kaldellis 2014, 465.

${ }^{25}$ Belfiore 2009, 160 gives more credit to Prokopios' explanation.
} 
man imperial temple, harbour or settlement. Applying the argumentum e silentio would ultimately compel us to reject much of Arrian's report as fabricated. ${ }^{26}$

And yet, skepticism seems to be well founded, given that Xenophon does not mention Pontic Athens in his Anabasis, which, among other exploits, reports the campaigns of the 10,000 Greek mercenaries in the area around Trapezous in $400 \mathrm{BC}$. The silence of Pseudo-Skylax ( $4^{\text {th }}$ cent. BC) and Strabo of Amaseia (late- $1^{\text {st }}$ cent. BC) may raise further suspicion. On closer inspection, however, I wonder if we should not give more credit to the rumours which Prokopios rejects too easily. First of all, it would be difficult to explain otherwise the existence of a temple of Athena in such a remote place on the fringes of the Greek world, if not beyond. Athena was none of the well-known emanations of the Anatolian, Armenian or Kolchian version of the Mother Goddess, who was venerated under the names of Kybele, Artemis, Demeter, Aphrodite, Anaitis or Phasiane. ${ }^{27}$ The latter was a typical city goddess, but no one has so far claimed that Pontic Athens ever was a polis in antiquity. Arrian's description reveals its nature as a fortified harbour place, perhaps originally an emporion. Since the massive mountain range blocks it from extensive trade with its hinterland, its orientation must have been maritime. In fact, Athena, was also venerated as protectress of sailors, in which capacity she is attested as of the days of Homer. Her role as patron deity of the Athenian League after the transfer of its treasury from Delos to the Athenian Akropolis in 454 BC further strengthened her maritime profile. ${ }^{28}$

Arrian does not directly address the Greekness of the place or its population, although I assume he took this for granted, since the place boasted a 'Hellenic' temple and called itself Athenai. Anthony Bryer - David Winfield have put forward an alternative explanation. Positing a Laz etymology (i.e. descent from a language related to Georgian or Kolchian), they suggest reading Athenai as 'Shady Place'. ${ }^{29}$ But, if so, the name would have come first, and the choice of the cult goddess would have resulted from a Greek reinterpretation of the toponymic.

${ }^{26}$ According to Bryer - Winfield 1985, 335, the columns of the Athena temple may still have been visible in $\mathrm{AD}$ 1820. The identification of those remains is as uncertain as their date.

${ }^{27}$ See, e.g., Braund 2018 for Aphrodite and Artemis in the Black Sea; Lazarenko et al. 2010 on the 'Pontic Mother' in Dionysopolis; Krapivina 2010 on mother goddesses (esp. Aphrodite) in Olbia; Roller 1999 on the Phrygian Kybele; Moga 2012 on the Persian Artemis in Pontos. Cf. Coşkun, forthcoming b for further bibliography.

${ }^{28}$ See Fenet 2016, 21-65 in general and Samons II 2000, 92-104 on the Athenian League, though both without discussing Pontic Athens. Also see below, with ns. 38-40 for references to further scholarship.

${ }^{29}$ Although admitting the standard view that the ancient kingdom of Laz was located in the Kolchian plain north-east of Anatolia, Bryer - Winfield 1985, 335 claim a further extension, beginning with Athenai. Moreover, they explain on p. 336f. (followed by Liddle 2003, 95): 'Athenai may well be derived, like so many place names of this area which begin with A-, from a Laz word - in this case meaning "the place where/there is shade." There is indeed another medieval site called Aténi in Georgia proper. By the same token, Rhizaion may be "the place where people (or soldiers) meet," and Mapavri suggests "leafy." Bellfiore 2009, 160 remains sceptical. Note that Arrian does not yet mention a settlement at the mouth of the Rhizaion, whereas Ptolemy 5.6.6 ascribes it a harbor or rather an anchorage (limen) and Prokopios a chorion. I would assume that the river name predates that of the settlement, which would question the suggested etymology further. I am unsure about Georgian Aténi, but the argument of Bryer - Winfield would only carry some weight, if a connection with Athens could reasonably excluded. 
While folk etymologies may indeed play an important role in ethnic constructs, I do not see why we should concede a Laz etymology to a place so far away from Kolchis or the Laz Kingdom proper. The idea of a prehistoric Greater Kolchis extending from the Caucasus to the territory of Trapezous is no more than modern wishful thinking. But even if this is granted, Herodotos locates the Kolchians (as vassals of the Achaemenid kings) north of the Lesser Caucasus. The Kolchians mentioned by Xenophon in the environs of Trapezous appear disconnected from the actual Kolchian territory, and their name is best explained as an ideological construct of the Sinopeans or Trapezuntines, which barely corresponded to a reality on the ground. ${ }^{30}$ It is telling that both Pliny and Prokopios locate the Lazoi in the Kolchian plain north of the Phasis, ${ }^{31}$ and Strabo implicitly tries to reject the existence of a little Kolchis around the city of Trapezous. ${ }^{32}$ We thus do not have to speculate when in the course of antiquity the Lazian ethnic was extended to the peoples of the eastern-Pontic mountains. ${ }^{33}$

In contrast, Athens in Attica could provide a much more plausible context. Its citizens began showing interest in Black Sea trade from the late- $6^{\text {th }}$ century onwards. While the activities of Miltiades (and probably also of the ancestors of the historiographer Thukydides) concentrated on and around the Propontis, the defeat of Xerxes and the conquest of the Hellespont and Byzantion reopened the Bosporos for them (479-478 BC). In the subsequent decades, Attic ware poured into the Euxine. That Athenian activities went beyond trade is best documented in Plutarch's Life of Perikles, under whom settlers were sent to Sinope. Probably around the same time, Amisos received new colonists from Athens under a certain Athenokles, as Strabo attests. ${ }^{34}$ Russell Meiggs has convincingly established the years $438 / 435$ as the most plausible timeframe, to coincide with the settlement of Amphipolis in southern Thrace by the strategos Hagnon (437/36 BC). Athenian engagement in the Black Sea resulted in 'abundant supplies from the Euxine, which flowed freely until the Sicilian disaster crippled Athenian naval power'. ${ }^{35}$ More recently, David Braund elaborated on Plutarch's testimony, arguing convincingly that we should conceive

\footnotetext{
${ }^{30}$ Xen. Anab. 4.8.8-23, esp. $\$ 22$, which locates Trapezous within Kolchis; cf. Arr. PPE 7.1; 11.1, who calls the Trapezuntines neighbours of the Kolchoi. See Janssens 1967, 36f. for my interpretation. For an advocate of a Greater Kolchis in the later Bronze and early Iron Ages, see Lordkipanidze 1996, 153-158. For a sober distinction between early Kolchian culture and the assumption of a unified kingdom, see Braund 1994, 89-92; cf. Tsetskhladze 1998, 115-129; 191, who sees the beginning of a Kolchian kingdom in Vani in the $6^{\text {th }}$ or $5^{\text {th }}$ century, but considers it relatively weak.

${ }^{31}$ Plin. Nat. Hist. 6.4.12; Prokop. Bell. 8.2.1-4; with Coşkun, forthcoming a, pace Braund 1991.

${ }^{32}$ Strab. Geogr. 12.3 .18 (548f.C) avoids the name Kolchis for the immediate environs of Trapezous, whereas other instances still reflect the tradition represented by Xenophon: Strab. Geogr. 7.4.3 (309C) and 12.3.13 (547C). See Coşkun in preparation b for discussion; also Podossinov 2012.

${ }^{33}$ Cf. Janssens 1967, 49f.

${ }^{34}$ Plut. Perikl. 20.1f.; Strab. Geogr. 12.3.14 (547C); cf. Nollé 1997; Surikov 2001 (reconstruction of Perikles' campaign and extended bibliography); Summerer 2005, 149f., 152 (defending the date in the mid430s BC); Belfiore 2009, 160 (though dating it to ca. 423 BC [which, however, is six years after Perikles' death] and denying a connection with Pontic Athens); Roller 2018, 702. Also see Ehrhardt 1999; Dan 2009, 84 (Sinope); Avram 2013, 26-30 and 39 (Amisos); 257-265 (Sinope).

35 Thuk. 4.102.3 and Plut. Perikl. 32.2 on Amphipolis; see Meiggs 1972/1999, 197-199; cf. Nollé 1997, 162f.; Lehmann 2008, 194f.; Braund 2005, 81-83; also de Boer 2005, 168-172, who, however, prefers a date shortly after $450 \mathrm{BC}$ for Perikles' mission (without engaging with Meiggs' arguments).
} 
of Perikles' campaign as a major feat which established effective Athenian hegemony over the entire Black Sea region. ${ }^{36}$

By the time the Peloponnesian War broke out, Sinope, Peiraios (Amisos) and Nymphaion were members of the Athenian League; Herakleia, Olbia and Apollonia possibly had the same status, and the Spartokid rulers of Pantikapaion were loyal friends of Athens. Athenian hegemony was not confined to those big poleis, but also included less important settlements. Many of them escaped the historical record, knowledge of others only barely came down to us, such as of Athenaiōn Limen near Theodosia on the Crimea, which is only attested in a Late Antique source. ${ }^{37}$

Based on the material evidence, we can be sure that Athens also entertained close connections along the Kolchian coast, not only with Phasis, but also with Pichvnari and other sites, ${ }^{38}$ including Gyenos and Dioskouri(a)s, which also figure in the Periplous of Pseudo-Skylax. ${ }^{39}$ By implication, this would result in the need to establish safe harbour places along the northern coast of Asia Minor. David Braund has added many observations drawn from literary and epigraphic

\footnotetext{
${ }^{36}$ Braund 2005, 80: 'Moreover, while Thucydides had no overwhelming reason to relate the Pontic expedition, Plutarch's narrative is impressively matter-of-fact: there is no great moralizing or rhetorical point here, but a narrative which, in itself, gives scant reason for suspicion as to its accuracy.' Previously, some scholars questioned the historicity of Plutarch's allegation or downplayed Athenian interest in the Black Sea, e.g., Ferrarese 1972; Mattingly 1996; cf. Welwei 1999, 383 n. 209. But see below for more positive assessments.
}

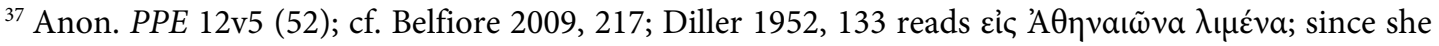
does not comment on this form, I assume that it is her slip. Less certain is the case of Agathopolis/Buaticum/Achtopol on the Bulgarian coast, which is discussed by de Boer 2005, 173-177. Meiggs 1972/1999 does not mention Olbia, Apollonia, Pontic Athens, Trapezous or Kolchian cities, but adds (p. 199) the take-over of Astakos in the Propontis, a former Megarite colony, and (p. 329, with Aischines 3.171 and Krateros, FGH 342 F 8) Nymphaion.

${ }^{38}$ On Athenian presence or dominance in the Kolchian area of Pichvnari and in Phasis, see Tsetskhladze 1994, 87-89; also 1998, 104-106, listing Sinope, Peraia (correct to Peiraios), Herakleia (see below, n. 40), Apollonia, Olbia and Nymphaion as new members of the Athenian League around 436); 107f. (Athenian settlement in Kolchis aided by Sinope); 178-180 (Athenian engagement as of 470s); 193. Also see Tsetskhladze 1999, 103-108; Kakhidze 2005, 116-118 (identifying Pichvnari as centre of Athenian trade in the area); Vickers - Kakhidze 2008. Cf. Marek 2003, 30.

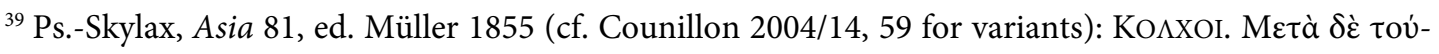

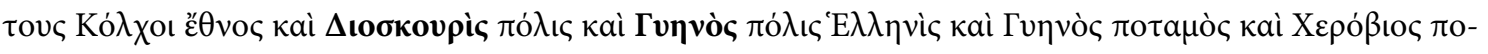

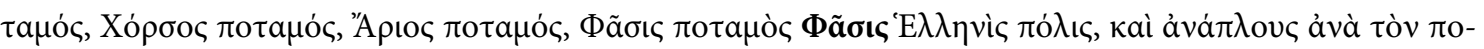

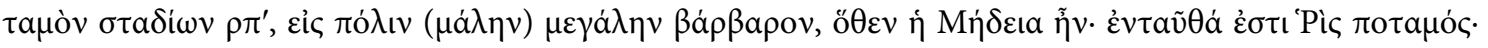

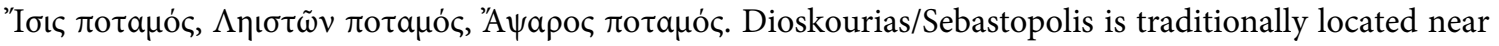
modern Sukhumi, Gyenos at Ochamchire and Phasis near Poti. To be added is Pityous, normally identified with modern Pitzunda/Bitchvinta: Strab. Geogr. 11.2.14 (496C); Plin. Nat. Hist. 6.5.16; Ptol. Geogr. 5.6.6. We have no literary or epigraphic evidence for the settlement (polis?) at Pichvnari in southern Kolchis. Most of these places were founded by the Milesians or at least under their authority, although Sinope seems to have taken over control of some of them after the fall of their mother city, though yielded to Athens for much of the $5^{\text {th }}$ century. Cf. esp. Tsetskhladze 1998 and 1999; also Ehrhardt 1988; Braund 1994; Lordkipanidze 1996; Nollé 1997. I shall propose different locations for Pityous, Dioskourias, Sebastopolis and Gyenos/Kygnos elsewhere (Coşkun in preparation a); cf. Kießling 1913, 1916. 
sources to prove how densely the whole of the Propontis and Black Sea littoral was integrated into the Athenian Empire in the third quarter of the $5^{\text {th }}$ century BC, probably starting with Perikles. ${ }^{40} \mathrm{He}$ corroborates his argument by showing that interest in Black Sea topics and Argonautic themes increased significantly in Athenian literature during the late $430 \mathrm{~s}$ and $420 \mathrm{~s} \mathrm{BC}^{41}$

Against this background, it is a plausible assumption that the Athenians tried to control as much of the littoral as possible. Their indirect control of Amisos and Trapezous would follow naturally from the league membership of Sinope, which had become the hegemonial power in the area after the destruction of its mother city Miletos by the Persians. Amisos was refounded or at least enhanced under Athenian auspices by the abovementioned Athenokles. ${ }^{42}$ Safeguarding an anchor place half-way between Trapezous and the mouth of the Akampsis respectively would have been a most plausible step around the same time, given the scarcity of fortified settlements on the littoral in-between Trapezous and Phasis on the one hand and the bad reputation of the mountain-dwellers in the Paryadres, Skydises and Moschian Mountains as dangerous barbarians on the other.

The silence of our literary tradition prior to the days of Arrian is, in fact, not too difficult to explain. To start with the Periplous of Pseudo-Skylax, this is normally considered a $4^{\text {th }}$-century-BC compilation of older periploi, possibly also containing materials of the late- $6^{\text {th }}$-century-BC periegetes Skylax of Karyanda. ${ }^{43}$ Since nothing in the Euxine sections implies autopsy, the second half of the $6^{\text {th }}$ century may indeed be the best fit for his information on the south-eastern littoral. On the one hand, the ancient name of the sizeable polis of Pichvnari is not yet mentioned (and thus

\footnotetext{
${ }^{40}$ Braund 2005 emphasizes an interest of Euxine cities to become allies of Athens, but questions local enthusiasm for receiving settlers (pp. 81f.). Further relevant are the Black Sea poleis catalogued in the highly fragmentary Tribute List of 425/24 BC (pp. 83f., 87, specifying the number of 44, although not a single name can be read for sure, with $I G \mathrm{I}^{3} 71 . \mathrm{IV}=$ PHI 72; cf. Meiggs 1972/1999, 328f., speaks of 40 to 50 cities; Mattingly 2008, 84). Also see Braund's considerations regarding the relations between Olbia, Sinope and Athens (pp. 83f.); Nymphaion and Pantikapaion, even wondering about Athenian influence on the replacement of the Archaianaktids by the Spartokids (pp. 85f.; cf. Mattingly 2008, 82f.); Kolchis, with Pichvnari, Dioskourias and King Aietes, who could be a contemporary of Perikles, since his grandson is mentioned by Xen. Anab. 5.6 .37 (p. 86f., cf. 90 with reference to Euripides' Medeia in 431 BC); Lamachos' campaign to Herakleia (pp. 87-89, with Thuk. 4.75; Just. 16.3.9-12; cf. Mattingly 2008, 82-84). Cf. Kakhidze 2005, 117 for listing Atina among the league members; Brock 2009, 159, also referencing Aristot. Pol. 1305b1-12 for Histria; Azoulay 2014, 73-76 for the Bosporan campaign in the context of Perikles' long-term imperial agenda. Cf. de Boer 2005; Summerer 2005, 149f.; Sens 2009, 165; Samons II 2016, 128, 134. It may further be of some bearing that Perikles' father Xanthippos had held a naval command in the Hellespontic area (Hdt. 8.131) and possibly concluded friendship relations (xeniai) there (Samons II 2016, 48 and 242 n. 48).

${ }^{41}$ Braund 2005, 91-98. One may add the innovation of the Medeia myth. It was probably around this time that she was fabricated to have moved from Iolkos or Korinth or Thebes to Athens, to become the wife of Aigeus, before returning to Kolchis with her son Medos. She is then said to have killed the usurper Perses, and her son to have conquered the Medes. See Apollod. Bibl. 1.9 .28 (147) and Hygin. Fab. 27; according to Strab. Geogr. 11.13 .10 (526C); cf. 11.2.18 (498C), Medeia returned together with Jason, and they were succeeded by their son Medos. For discussion, see Gantz 1993, 372f. and De Siena 2001, 90-93; cf. Mariotta - Magnelli 2012, 195.

${ }^{42}$ See below, n. 50, on Sinope.

${ }^{43}$ See von Arnim 1927, 635-646, esp. 644; cf., e.g., Tsetskhladze 1998, $15 f$.
} 
escapes us entirely); on the other hand, Pseudo-Skylax lists three poleis in-between the Arion River (Apsaros?/Akampsis?) and Trapezous: Limne, Odeinios, Becheiria, names that vanished from our records thereafter. ${ }^{44}$ There is a good chance that Alain Silberman is right and Odeinios is related to the abovementioned river Adienos or town Ardinium. ${ }^{45}$ If so, then Limne could point to a harbour nearby, possibly a former apoikia of the Milesians or Phokaians that the Athenians resettled and renamed after their own home city. ${ }^{46}$ Limne is classified as a polis, which probably reflects its status not long after its first foundation. That this city did not live on may be due to the repercussions of the Ionian Revolt (499-494 BC). This leaves open whether the sanctuary at Athenai had been dedicated to Athena (Polias?) before the Athenians took over the place. ${ }^{47}$ This is possible, but a foundation under Athenian auspices in the $430 \mathrm{~s}$ BC is the most likely. ${ }^{48}$

\section{3) Pontic Athens after the End of Athenian Thalassocracy}

Athenian hegemony in the Euxine Sea was shortlived and probably disintegrated in the aftermath of the Sicilian disaster in 413 BC. Alkibiades could briefly re-establish the Athenian 'lifeline' or 'wheat-route' through the Aegean, to reconnect Attica with the grain producers in the Black Sea, but it is unlikely that the Athenians had the resources to reassert their imperial rule in the area. Any hopes of a revival of their arche were dashed at Aigospotamoi in 405 BC. When Xenophon joined Prince Cyrus for his Persian campaign in 401 BC, Athenian thalassocracy was history. Cyrus' death at Ktesiphon forced the 10,000 Greek mercenaries to withdraw ingloriously. In his Anabasis, Xenophon reports their march along the Tigris through Armenia to Trapezous. Although they campaigned in the immediate environs of this city, there is no reason to assume that they went more than three days east, whereas Athenai lay at least five or six days east. As a whole, the Anabasis reflects that Xenophon had no interest in geo-historical explorations that exceeded his immediate itinerary or potential strategical considerations. Indeed, one might even gain the impression that his conception of Trapezous before his physical arrival there had been very limited, and that he is not assuming any detailed knowledge among his readers in the Greek motherland either, when he wrote his account a few decades after the

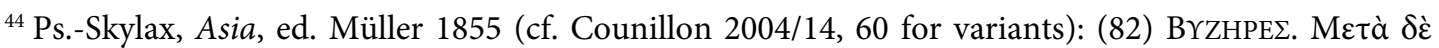

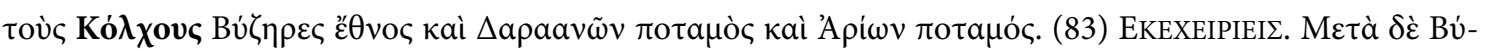

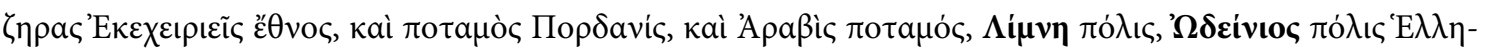

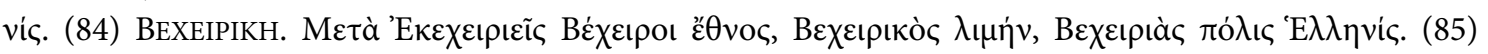

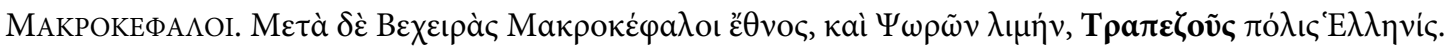

${ }^{45}$ Counillon 2004/14, 60 reads Hodeinios. See above, with n. 18.

${ }^{46}$ The identity of Limne and Athenai is also suggested by Belfiore 2009, 160. Without this assumption, Wikipedia.com s.v. Pazar, Rize is the only reference I could find so far for the assumption of a Milesian origin of Athenai, though the $8^{\text {th }}$ century BC is certainly too early; cf. Ehrhardt 1988 for context.

${ }^{47}$ Athena Polias played an important role in Miletos, Phokaia and Teos as well as in their colonies, although Ehrhardt 1988, 162-164 points out that her cult lost prominence after Miletos quitted the Athenian League in 412 BC. Pontic Athens is not considered by Ehrhardt. A possible hint at Phokaian presence in the area could be the Leukotheion in Kolchis, see Coşkun, forthcoming b.

${ }^{48}$ This is not to say that the Athenians actively pursued the spread of Athena's cult, other than that they compelled the league members to contribute to the cult expenses for Athena Parthenos at Athens, and perhaps that either Athenian settlers or allies were sometimes inclined to establish cults for 'Athena who rules in Athens', as attested on Samos, Chalkis and Kos; see Parker 2008, 146-150; cf. Giovannini 2008. 
events. ${ }^{49}$ Hence, Xenophon's Anabasis might not even have mentioned Pontic Athens, had it been an average-sized polis at the time.

The evidence that is currently available does not permit us to know whether Athenai was still a functional polis or at least polichnion around $400 \mathrm{BC}$ or had been abandoned by most of its inhabitants. It may have been no more than an isolated anchorage, possibly not yet taken over by Sinope. At any rate, the latter city-state was already established as the new power in the area when Xenophon sojourned in Trapezous in $400 \mathrm{BC} .{ }^{50}$ We hear little about the Pontic coast over the next centuries, but Sinope may have maintained its lead until it gradually ceded control to the Mithradatic rulers. Eventually, King Pharnakes I of Pontos captured the city in $183 \mathrm{BC}$, to turn it into his main residence. ${ }^{51}$

But the best days of the Sinopean eastern trade network may well have been over by this time. There are various indications that point to a regional climate change, which resulted in the rise of the sea level and the gradual conversion of large parts of the coast into swamp land. Kolchian harbours in particular became ever more difficult to access and thus costly to maintain. According to Gocha Tsetskhladze, this is the main reason why Pichvnari was ultimately abandoned. This reconstruction aligns with Strabo's descriptions of the sandy estuaries along the Kolchian coast, and possibly also with Prokopios' opaque remark on the difficulty to navigate along the south-eastern edge of the Black Sea. ${ }^{52}$

Most likely, then, natural and economic reasons induced Sinope to concentrate on fewer anchorages, which would have been easier to run while providing access to more profitable busi-

\footnotetext{
${ }^{49}$ The exact date is controversial. Some regard his expulsion from Skillos in $371 \mathrm{BC}$ or the renewed alliance between Sparta and Athens in 369 BC as terminus post quem (e.g., Mather - Hewitt 1962, 27; 30), while others consider a time in the 380s BC possible (e.g., Breitenbach 1967, 1639-1644). Cf. Cawkwell 2004 and Flower 2012, 29f. for discussion. Also contested is the question whether Xenophon drew on literary sources, as Stylianou 2004 suggests. I agree with Flower 2012, 61 that he is not likely to have used literary sources such as geographical accounts, but I find it unlikely that he should not have used diaries or memoires written by himself or other participants during or shortly after the campaign. Rood 2010, 52, 61-64 remains undecided, whereas Rood 2011 suggests that Xenophon manipulated distances for rhetorical purposes. I rather think that some of the inconsistencies (esp. measuring by stades, parasangs or days) reflect his written sources, which Xenophon closely followed, and that these largely drew on the various local guides in the first place.

${ }^{50}$ Xen. Anab. 4.8.22 introduces Trapezous as a Sinopean colony, just as Kotyora (5.5.3), and in the context of the negotiations with ambassadors from Sinope, it becomes clear that they were paying tribute (together with Kerasus) to the city, which, in turn, was concerned about their safety (5.5.7-12). Cf. Erciyas 2007, esp. 1199; also Dan 2009, 84-93.

${ }^{51}$ For Pharnakes I and Sinope, see Polyb. 23.9.2, cf. Heinen 2005 and Avram 2016; also Erciyas 2007 and Dan 2009, 93-96.

${ }^{52}$ See Tsetskhladze 1994, 90; 1998, 55f.; 1999, 114. See above, n. 38 for Pichvnari. - Perhaps Prokop. Bell. 8.2.1.7-9 implies a similar condition, when he pretends that the dangerous current of the Akampsis compelled sailors to bypass the estuary by steering 'towards the middle of the sea'. But this causality is unlikely, given the breadth of the Akampsis at its mouth in antiquity (see the map of Braund - Sinclair 1997/2000, BA 87), and also considering Strabo's comment on the smoothness of the estuaries south of the Phasis: Strab. Geogr. 11.2.17 (498C). Prokopios' confusion may be due to his conflation of the Boas/ Akampsis with the Phasis in 2.29.3.14, 16; see Dewing - Kaldellis 2014, 138 n. 272 and p. 464 n. 740; Dan 2016, 259; Coşkun, forthcoming a.
} 
ness partners. Gradually, the larger trade fleets would bypass Athenai just as Odeinios or Pichvnari and commute directly from Sinope, Amisos or Trapezous to Phasis, Dioskourias or Pityous. These are the routes repeatedly mentioned by Strabo and Arrian. ${ }^{53}$ Trapezous, too, must have suffered substantially when the economy was shrinking. Although Strabo mentions this city frequently, he addresses it as the last outpost of Greek civilization in north-eastern Pontos and once even as the last station before Phasis. He has surprisingly little to say about its harbour or urban centre. ${ }^{54}$ Likewise, the attention that Arrian pays this city is largely homage to Xenophon's Anabasis..$^{55}$ At least, Trapezous had fertile plains in its hinterland so that it could sustain itself much better than others.

This reconstruction would sufficiently explain why Strabo was unaware of any settlements between Trapezous and Phasis City ${ }^{56}$ In the same light, we should read the silence of PseudoSkymnos, whose Periplous was written sometime in the $2^{\text {nd }}$ half of the $2^{\text {nd }}$ century BC, as well as the lack of poleis in Arrian's account of the area. This does, of course, not exclude the continued existence of some villages along the coast, such as the one around the sanctuary of Athena, but it required a serious storm for Arrian even to take note of Pontic Athens.

Not even the fortification of the eastern limes under the Flavian Emperors brought about a change for the better to the eastern Pontic and southern Kolchian coast, as indirectly attested by Arrian and perhaps also implied by Claudius Ptolemy. Since Athenai does not resurface in our literary evidence before the Tabula Peutingeriana, just as Ardinium/Odeinios, the intensified infrastructure of the Later Roman Empire may have led to a limited surge. Prokopios can be adduced as a witness for this development: in the $6^{\text {th }}$ century: he is the first to mention the village Susurmena at the eastern end of Trapezuntine territory, close to the mouth of the Rhizaion, where there was also a chorion. Athenai is finally addressed as a 'village' (kome), and Apsaros, which Arrian had mentioned as an important garrison, had developed into a larger city. ${ }^{57}$

${ }^{53}$ Strab. Geogr. 11.2.14 (496C) for Bata (between the Sindians and Caucasian Achaians) - Sinope; 11.2.16 (498C) for Dioskourias - Phasis; 11.2.17 (498C) for Phasis - Amisos and Phasis - Sinope; 12.3.17 (548C) for Amisos - Trapezous - Phasis (also Kolchis). Also Arr. PPE 10.4 for Trapezous - Sebastopolis/ Dioskourias, although this summarizes the more detailed preceding periplous (PPE 3-10); 17.1 for Trapezous - Diskourias/Sebastopolis; 18.1 for Dioskourias - Pityous. A minor change is indicated by Plin. Nat. Hist. 6.4.12-14, who gives the distance for Trapezous - Apsaros - Phasis - Sebastopolis. Apsaros (modern Gonio) on the bank of the Akampsis had developed into an important military fortress, see below, n. 57 for further references.

${ }^{54}$ The only thing he has to say - beyond describing its environs - is that it was a Greek city: Strab. Geogr. 12.3.17f. (548C), where also the rulers of Pontos are listed; cf. 13.3.28 (555C). Trapezous as landmark or end point: Strab. Geogr. 7.4.3 (309C); 7.6.2 (320C). Other mention: 7.F21b; 11.2.18 (499C).

${ }^{55}$ Arr. PPE 1f.; on his literary design and his use of Xenophon, see Rood 2011. Cf. Erciyas 2007, 1199 'Trapezus was relatively insignificant until at least the $9^{\text {th }}$ century.'

${ }^{56}$ Strab. Geogr. 11.2.17 (498C) and 12.3.13 (547C).

${ }^{57}$ Prokop. Bell. 8.2.12f. Also Bell. 8.2.2.11-14; 8.2.4.1 and Arr. PPE 6.1 on Apsaros; cf. Plin. Nat. Hist. 6.4.12 (as below) and CIL 10.1.1202 = ILS 2660; and Bryer - Winfield 1985, 350f.; Braund 1994, 181-187; Silberman 1995, 27f.; Tsetskhladze 1998, 117-124; Liddle 2003, 5-12; 95f. But the southern littoral of Kolchis may not yet have recovered in the $6^{\text {th }}$ century AD: Prokop. Bell. 8.2.4.29, cf. Strab. Geogr. 11.2.17 (498C); Plin. Nat. Hist. 6.10.29: Colchicae solitudines; Arr. PPE 7-11; Coşkun, forthcoming a, pace Braund 1991. 


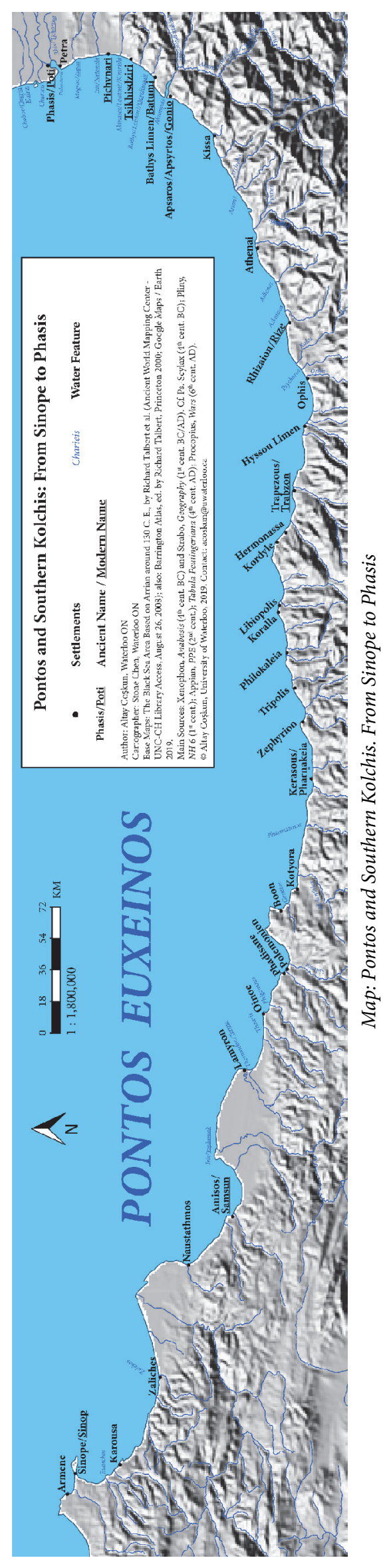




\section{Bibliography}

Avram - Hind - Tsetskhladze A. Avram - J. Hind - G. R. Tsetskhladze, The Black Sea Area, in: 2004 M. H. Hansen - T. H. Nielsen (eds.), An Inventory of Archaic and Classical Poleis, Oxford 2004, 924-973.

Avram 2013

A. Avram, Prosopographia Ponti Euxini externa, Leuven 2013.

Avram 2016

Azoulay 2014

A. Avram, On the Date of the Treaty between Pharnaces and Tauric Chersonese, in: J. -Chr. Couvenhes (ed.), La symmachia comme pratique du droit international dans le monde grec, Besançon 2016, 213-237.

V. Azoulay, Pericles of Athens. Translated by Janet Llolyd, forworded by Paul Cartledge, Princeton NJ 2014. (French original: Périclès: La démocratie athénienne à l'épreuve du grand homme, Paris 2010.)

Bauslaugh 1979

Belfiore 2009

Billerbeck 2006

Braund 1991

Braund 1994

Braund 2005

Braund 2018

Braund - Sinclair 1997/2000

Breitenbach 1967

Brock 2009
R. A. Bauslaugh, The Text of Thucydides IV 8.6 and the South Channel at Pylos, JHS 99, 1979, 1-6.

S. Belfiore, Il Periplo del Ponto Eusino di Arriano e altri testi sul Mar Nero e il Bosforo. Spazio geografico, mito e dominio ai confine dell' Impero Romano, Venice 2009.

M. Billerbeck, Stephani Byzantii Ethnica, vol. 1 (A-Г), Berlin 2006.

D. Braund, Procopius on the Economy of Lazia, CQ 41, 1991, 221225.

D. Braund, Georgia in Antiquity: A History of Colchis and Transcaucasian Iberia, 550 BC-AD 562, Oxford 1994.

D. Braund, Pericles, Cleon and the Pontus: The Black Sea in Athens c. 440-421, in: D. Braund (ed.), Scythians and Greeks. Cultural Interactions in Scythia, Athens and Early Roman Empire (Sixth Century BC - First Century AD), Exeter 2005, 80-99.

D. Braund, Greek Religion and Cults in the Black Sea Region: Goddesses in the Bosporan Kingdom from the Archaic Period to the Byzantine Era, Cambridge 2018.

D. Braund - T. Sinclair, Map 87 Pontus-Phasis (1997), in: R. J. A. Talbert (ed.), Map by Map Directory to Accompany Barrington Atlas of the Greek and Roman World, Princeton 2000, 1226-1242.

H. R. Breitenbach, Xenophon (6) von Athen, RE 9A.2, 1967, 15691928.

R. Brock, Did the Athenian Empire Promote Democracy?, in: J. $\mathrm{Ma}-\mathrm{N}$. Papazarkadas - R. Parker (eds.), Interpreting the Athenian Empire, London 2009, 149-166. 
Bryer - Winfield 1985

Cawkwell 2004

Coşkun forthcoming a

Coşkun forthcoming $b$

Coşkun, in preparation a

Coşkun, in preparation $b$

Counillon 2004/14

Dan 2009

Dan 2016

de Boer 2005

De Siena 2001
A. Bryer - D. Winfield, The Byzantine Monuments and Topography of the Pontos, 2 vols., Washington DC 1985.

G. Cawkwell, When, How and Why did Xenophon Write the Anabasis, in: R. L. Fox (ed.), The Long March. Xenophon and the Ten Thousand, New Haven 2004, 47-67.

A. Coşkun, Akampsis, Boas, Apsaros, Petra, Sebastopolis: Rivers and Forts on the Southern Littoral of Kolchis, forthcoming in: a FS (ca. 2020).

A. Coşkun, Searching for the Sanctuary of Leukothea in Kolchis, in: A. Coşkun (ed.), Studies in the Mithradatic Dynasty, the Bosporan Kingdom and Ethnic Constructs around the Black Sea Littoral. Methodological Advances and Interdisciplinary Perspectives, forthcoming ca. 2020/21.

A. Coşkun, Dioskourias in the Recess of the Black Sea. (Re-) Locating Greek \& Roman Cities along the Northern Coast of Kolchis (Gyenos, Dioskourias, Sebastopolis, Pityous and Herakleion), in: preparation a.

A. Coşkun, The Boundary between Trapezus and Kolchis, and the Eastern Extension of the Kingdom of Deiotaros Philorhomaios, in: preparation $b$.

P. Counillon, Pseudo-Skylax: le périple du Ponte Euxin, Paris 2004 /14; online edition 2014: https://www.academia.edu/ 6425553 /Patrick_Counillon_Pseudo-Skylax_le_Périple_du_Pont-Euxn. _Texte_traduction_commentaire_philologique_et_historique.Au sonius_éditions_2004.

A. Dan, Sinope, 'capitale' pontique, dans la géographie antique, in: H. Bru - F. Kirbihler - S. Lebreton (eds.), L'Asie Mineure dans l'Antiquité: échanges, populations et territoires, Rennes 2009, $67-$ 131.

A. Dan, The Rivers Called Phasis, AWE 15, 2016, 245-277.

J. G. de Boer, The Foundation of Agathopolis/Alaeouteichos and the Athenian Black Sea Policy in the $5^{\text {th }}$ Century BC, in: D. Kacharava - M. Faudot - É. Geny (eds.), Pont-Euxine et Polis. Polis Hellenis and Polis Barbaron. Actes du $\mathrm{X}^{\mathrm{e}}$ Symposium de Vani - 23-26 septembre 2002, Besançon 2005, 167-180.

A. A. De Siena, Medea e Medos, eponimi della Media, in: G Traina (ed.), Studi sull'XI libro dei Geographika di Strabone, Galatina, Lecce 2001. 
Dewing - Kaldellis 2014

Dewing 1914-1928

Diller 1952

Ehrhardt 1988

Ehrhardt 1999

Erciyas 2007

Falconer 1805

Fenet 2016

Ferrarese 1972

Flower 2012

Gantz 1993

Giovannini 2008

Heinen 2005

Hercher - Eberhard 1885

Janssens 1967
H. B. Dewing - A. Kaldellis, Prokopios, The Wars of Justinian. Translated by H. B. Dewing. Revised and Modernized, with an Introduction and Notes, by Anthony Kaldellis. Maps and Genealogies by Ian Mladov, Indianapolis 2014.

H. B. Dewing, Procopius, London. 1914-1928. Drawn from the Perseus Collection.

A. Diller, The Tradition of the Minor Greek Geographers, Lancaster PA 1952.

N. Ehrhardt, Milet und seine Kolonien, $2^{\text {nd }}$ ed., Frankfurt a.M. 1988.

N. Ehrhardt, Ktistai in den Argonautika des Apollonios Rhodios. Beobachtungen zur Entwicklung von Gründungstraditionen in Kyzikos, Kios, Herakleia Pontike und Sinope (Asia Minor Studien 16, Studien zum antiken Kleinasien), Bonn 1999, 23-46.

D. B. Erciyas, Cotyora, Kerasus and Trapezus: The Three Colonies of Sinope, in: D. V. Grammenos - E. K. Petropoulos (eds.), Ancient Greek Colonies in the Black Sea, vol. 2, Oxford 2007, 11951206.

W. Falconer, Arrian's Voyage around the Black Sea, Oxford 1805. Drawn from Wikisource.

A. Fenet, Les dieux olympiens et la mer. Espaces et pratiques cultuelles, Rome 2016.

P. Ferrarese, La spedizione di Pericle nel Ponto Eusino, CISA 2, 1972, 7-19.

M. A. Flower, Xenophon's Anabasis, or The Expedition of Cyrus, Oxford 2012.

T. Gantz, Early Greek Myth. A Guide to Literary and Artistic Sources, Baltimore 1993.

A. Giovannini, The Parthenon, the Treasury of Athena and the Tribute of the Allies, in: P. Low (ed.), The Athenian Empire, Edinburgh 2008, 150-163.

H. Heinen, Mithradates VI. Eupator, Chersonesos und die Skythenkönige. Kontroversen um Appian, Mithr. 12f. und Memnon 22,3f., in: A. Coşkun (ed.), Roms auswärtige Freunde in der späten Republik und im frühen Prinzipat, Göttingen 2005, 75-90.

R. Hercher - A. Eberhard, Arriani Nicomediensis Scripta Minora, Leipzig 1885. Drawn from the Perseus Collection.

E. Janssens, Trébizonde en Colchide, Brussels 1967. 
Kahrstedt 1934

Kakhidze 2005

Kießling 1913

Krapivina 2010

Lazarenko et al. 2010

Lehmann 2008

Lemcke 2016

Liddle 2003

Lordkipanidze 1996

Magie 1950

Marek 2003

Marek 2010

Mariotta - Magnelli 2012

Mather - Hewitt 1962

Mattingly 1996
U. Kahrstedt, Staatsgebiet und Staatsangehörige in Athen, Stuttgart 1934.

A. Kakhidze, Athens and the Black Sea Area in the Late Archaic and Classical Periods, in: D. Kacharava - M. Faudot - É. Geny (eds.), Pont-Euxine et Polis. Polis Hellenis and Polis Barbaron. Actes du X $\mathrm{X}^{\mathrm{e}}$ Symposium de Vani - 23-26 septembre 2002, Besançon 2005, 115-118.

E. Kießling, Hippos (6) RE 8.2, 1913, 1915-1917.

V. V. Krapivina, Home Sanctuaries in the Northern Black Sea Littoral, in: E. K. Petropoulos - A. A. Maslennikov (eds.), Ancient Sacral Monuments in the Black Sea, Thessalonike 2010, 127-170.

I. Lazarenko - E. Mircheva - R. Encheva - N. Sharankov, The Temple of the Pontic Mother of Gods in Dionysopolis, in: E. K. Petropoulos - A. A. Maslennikov (eds.), Ancient Sacral Monuments in the Black Sea, Thessalonike 2010, 13-62.

G. A. Lehmann, Perikles. Staatsmann und Stratege im klassischen Athen, Munich 2008.

L. Lemcke, Imperial Transportation and Communication from the Third to the Late Fourth Century: The Golden Age of the cursus publicus, Brussels 2016.

A. Liddle, Arrian. Periplus Ponti Euxini, London 2003.

O. Lordkipanidze, Das alte Georgien (Kolchis und Iberien) in Strabons Geographie. Neue Scholien, deutsch von Nino Begiaschwili, Amsterdam 1996.

D. Magie, Roman Rule in Asia Minor to the End of the Third Century after Christ, 2 vols., Princeton/NJ 1950.

C. Marek, Pontus et Bithynia. Die römischen Provinzen im Norden Kleinasiens, Mainz 2003.

C. Marek, Geschichte Kleinasiens in der Antike, Munich 2010.

G. Mariotta - A. Magnelli, Diodoro Siculo, Biblioteca storica, Libro IV, Commento storico, Milan 2012.

M. W. Mather - J. W. Hewitt (eds.), Xenophon's Anabasis, Books I-IV, Norman OK 1962.

H. B. Mattingly, Athens and the Black Sea in the Fifth Century BC, in: O. Lordkipanidzé - P. Lévêque (eds.), Sur les traces des Argonautes. Actes du $6^{\mathrm{e}}$ symposium de Vani (Colchide) 22-29 septembre 1990, Paris 1996, 151-157. 
Mattingly 2008

Meiggs 1972/1999

Miller 1916

Moga 2012

Müller 1855

Müller 1883/1901

Nobbe 1843-45/1966

Nollé 1997

Olshausen - Biller 1984

Parker 2008

Podossinov 2012

Rémy 1989

Roller 1999

Roller 2018

Rood 2010

Rood 2011
D. Mattingly, Periclean Imperialism, in: P. Low (ed.), The Athenian Empire, Edinburgh 2008, 81-110.

R. Meiggs, The Athenian Empire, Oxford 1972, repr. 1999.

K. Miller, Itinera Romana, Stuttgart 1916.

I. Moga, Strabo on the Persian Artemis and Mên in Pontus and Lydia, in: G. R. Tsetskhladze (ed.), The Black Sea, Paphlagonia, Pontus and Phrygia in Antiquity. Aspects of Archaeology and Ancient History, Oxford 2012, 191-195.

K. Müller, Geographi Graeci Minores, vol. 1, Leipzig 1855.

C. Müller, Claud. Ptolemaei Geographica (lib. 1-5), Paris 1883/ 1901 (quoted after Stückelberger - Graßhoff 2006, vol. 1, 46).

C. F. A. Nobbe, Claudii Ptolemaei Geographia, Leipzig 1843-45, repr. Hildesheim 1966.

M. K. Nollé, Koloniale und mythische Verwandtschaften der Stadt Amisos in Pontos, in: J. Nollé - B. Overbeck - P. Weiß (eds.), Internationales Kolloquium zur kaiserzeitlichen Münzprägung Kleinasiens (Nomismata 1), Milan 1997, 157-164.

E. Olshausen - J. Biller, Historisch-geographische Aspekte der Geschichte des Pontischen und Armenischen Reiches. Teil I: TAVO B 29/1, Wiesbaden 1984.

R. Parker, Religion and the Athenian Empire, in: P. Low (ed.), The Athenian Empire, Edinburgh 2008, 150-163.

A. V. Podossinov, Bithynia, Paphlagonia and Pontus on the Tabula Peutingeriana, in: G. R. Tsetskhladze (ed.), The Black Sea, Paphlagonia, Pontus and Phrygia in Antiquity. Aspects of Archaeology and Ancient History, Oxford 2012, 203-206.

B. Rémy, Les carrières sénatoriales dans les provinces romaines d'Anatolie au Haut-Empire (31 av. J.-C. - 284 ap. J.-C.) (PontBithynie, Galatie, Cappadoce, Lycie-Pamphylie et Cilicie), Istanbul 1989.

L. E. Roller, In Search for the Mother God, Berkeley CA 1999.

D. W. Roller, A Historical and Topographical Guide to the Geography of Strabo, Cambridge 2018.

T. Rood, Xenophon's Parasangs, Journal of Hellenic Studies 130, 2010, 51-66.

T. Rood, Black Sea Variations: Arrian's "Periplus”, Cambridge Classical Journal 57, 2011, 137-163. 
Roos - Wirth 1967

Samons II 2000

Samons II 2016

Sens 2009

Silberman 1995

Stückelberger - Graßhoff 2006

Stylianou 2004

Summerer 2005

Surikov 2001

Tomaschek 1896

Tsetskhladze 1994

Tsetskhladze 1998

Tsetskhladze 1999

Veh 1978

Vickers - Kakhidze 2008

von Arnim 1927
A. G. Roos - G. Wirth, Flavii Arriani quae existant omnia, Leipzig 1967.

L. J. Samons II, Empire of the Owl. Athenian Imperial Finance, Stuttgart 2000.

L. J. Samons II, Pericles and the Conquest of History. A Political Biography, Cambridge 2016.

U. Sens, Kulturkontakt an der östlichen Schwarzmeerküste, Langenweißbach 2009.

A. Silberman, Arrien, Périple du Pont-Euxin, Paris 1995.

A. Stückelberger - G. Graßhoff (eds.), Ptolemaios, Handbuch der Geographie, vol. 1: Einleitung und Buch 1-4; vol. 2: Buch 5-8 und Indices, Basel 2006.

P. J. Stylianou, One Anabasis or two?, in: R. L. Fox (ed.), The Long March. Xenophon and the Ten Thousand, New Haven 2004, 6896.

L. Summerer, Amisos - eine Griechische Polis im Land der Leukosyrer, in: D. Kacharava - M. Faudot - É. Geny (eds.), Pont-Euxine et Polis. Polis Hellenis and Polis Barbaron. Actes du X $\mathrm{X}^{\mathrm{e}}$ Symposium de Vani - 23-26 septembre 2002, Besançon 2005, 129-165.

I. E. Surikov, Historico-Geographical Questions Connected with Pericles' Pontic Expedition, ACSS 7, 2001, 341-366.

W. Tomaschek, Athenai (7), RE 2, 1896, 2022.

G. R. Tsetskhladze, Colchians, Greeks and Achaemenids in the $7^{\text {th }}$ $5^{\text {th }}$ Centuries BC: A Critical Look, Klio 76, 1994, 78-102.

G. R. Tsetskhladze, Die Griechen in der Kolchis, Amsterdam 1998.

G. R. Tsetskhladze, Pichvnari and Its Environs, 6th c BC-4th c AD, Paris 1999.

O. Veh, Prokop, Gothenkrieg. Griechisch-deutsch, $2^{\text {nd }}$ ed. Munich 1978.

M. Vickers - A. Kakhidze, A Kolchian and Greek Settlement: Excavations at Pičvnari 1967 to 2005, in: Proceedings of the Danish National Research Foundation Centre for Black Sea Studies Conference 'Meetings of Cultures in the Black Sea Region: between Conflict and Coexistence' 2006, Aarhus 2008, 131-148. http:// www.pontos.dk/publications/books/BSS\%208.

H. von Arnim, Skylax (2), RE 3A.1, 1927, 615-646. 
Welwei 1999

K. -W. Welwei, Das klassische Athen. Demokratie und Machtpolitik im 5. und 4. Jahrhundert, $2^{\text {nd }}$ ed. Darmstadt 1999.

Websites Cited (22 Feb. 2019):

Google Maps: https://www.google.com/maps

Perseus Collection - Greek and Roman Materials:

http://www.perseus.tufts.edu/hopper/collection?collection=Perseus\%3Acollection\%3AGreco-

Roman

Wikipedia: https://www.wikipedia.org

Wikisource: https://en.wikisource.org

\section{Pontos Atina's1}

\section{Kendi Tarihî-Coğrafî İçeriğinde bir Atina Emporion'u}

Öz

Tüm antik yerleşimler içerisinde en az öneme sahip olan ve Athenai olarak adlandırılan yerleşim Pontos kıyısında Trapezous'un doğusunda yer almaktadır. Yerleşim ismini 20. yüzyıl içlerine kadar muhafaza etmiş ve daha sonra Pazar olarak yeniden adlandırılmıştır. Arrianus'un bu khorionun (günümüze kalan) ilk tasvirini bize sunması, Roma donanmasının bazı bölümlerini onun limanına demirlemesini zorunlu kılan bir firtına sebebiyledir (İS 132). İS 6. yüzyılda Prokopios sadece daha ünlü bir adaşı tarafından kurulmuş olduğunu gösteren yerel geleneği yalanlamak adına bu köyden bahseder. Bilim insanları bu şüpheci yaklaşımı paylaşmışlardır ve bundan dolayı Pontos Atina'sını büyük oranda dipnotlara indirgemişler ya da onu tümden unutulmaya mahkûm etmişlerdir. Fakat hiçbir şey, bunu Perikles'in Karadeniz’e yaptığı gezinin (yak. İÖ 437/5) bir sonucu olarak düşünmekten daha mantıklı değildir. Athenai, Limne adındaki bir Miletos apoikiası olarak tarih öncesi bir geçmişe sahip olabilir. Atina thalassokrasisinin (deniz hükümranlığının) yıkılmasının (İÖ 405) ardından oynamış olduğu rol ise daha az kesindir. İÖ 2. yüzyıl başlarında Pontos Krallığı'na dahil edilmeden olasılıkla Sinope egemenliğinde yer almıştır. Ancak Pontos Atina'sı bu dönemde Trapezous ve Phasis arasındaki alanda gerçekleşen ekonomik çöküşü yaşamıştır. Her şeye rağmen bir köy olarak varlığını sürdürmüştür ve bu durum da bir polikhnion olarak varlığını devam ettirse de yüzyıllar boyu tarihi kayıtlardan nasıl gözden kaçabildiğini göstermektedir.

Anahtar Sözcükler: Pontos Atina's1/Atina/Pazar, Atina, Trabzon/Trapezous, Miletos, Perikles, Arrianos, Prokopios, Karadeniz ticareti.

\section{Pontic Athens}

\section{An Athenian Emporion in Its Geo-Historical Context}

\section{Abstract}

The least significant of all ancient settlements called Athenai was located east of Trapezous on the Pontic coast. It maintained its name well into the $20^{\text {th }}$ century, when its successor was renamed Pazar. That Arrian provides us with the first (surviving) description of this chorion is due to a storm that compelled him to anchor parts of the Roman fleet in its little harbour (AD 132). 
In the $6^{\text {th }}$ century, Prokopios mentions the village only to refute the local tradition that it had been founded by its more famous namesake. Scholars have shared this skepticism and thus largely relegated Pontic Athens to footnotes or condemned it to complete oblivion. But nothing is more plausible than regarding it as a result of Perikles' expedition to the Euxine (ca. 437/35 BC). Athenai may have a pre-history as a Milesian apoikia called Limne. Less certain is the role it played after the breakdown of Athenian thalassocracy (405 BC). It probably stood under Sinopean hegemony, before being absorbed into the Pontic kingdom in the early- $2^{\text {nd }}$ century BC. By then, however, Pontic Athens had shared the economic downturn of the area between Trapezous and Phasis. It lived on as a village regardless, and thus demonstrates that a polichnion could escape the historical record for centuries without ceasing to exist.

Keywords: Pontic Athens/Atina/Pazar, Athens, Trapezous, Miletos, Perikles, Arrian, Prokopios, Black-Sea trade. 